\title{
PATOLOGI BAHASA PADA JUDUL BERITA SURAT KABAR WARTA KOTA
}

\author{
Siti Jubei \\ Program Studi Pendidikan Bahasa Indonesia \\ Fakultas Bahasa dan Seni Universitas Indrasprasta PGRI \\ jubei.lppmunindra@gmail.com
}

\begin{abstract}
Abstrak
Penelitian ini bertujuan untuk memperoleh data empiris tentang penggunaan kata atau frase dalam juduljudul berita yang menimbulkan patologi. Metode yang digunakan dalam penelitian ini adalah metode deskriptif dengan teknik analisis isi yang memberikan gambaran dan perhatian penuh pada media informasi dengan aktual, yaitu fakta atau data yang ada pada media informasi. Adapun sampel diambil dari koran Warta Kota periode April-Mei. Hasil penelitian ini menunjukkan patologi kata pada judul berita surat kabar warta kota mencapai 23\%. Dari data tersebut. peneliti dapat menyimpulkan bahwa penggunaan kata yang menimbulkan patologi masih tergolong rendah dan hal itu masih dapat ditoleransi.
\end{abstract}

Kata Kunci: patologi, bahasa, berita, surat kabar

\begin{abstract}
Absract
The eim of this study is to get the empirical data of the use of word or phrase in the topic of news that can occur a patology in language. The method used in this study is descriptire method with content analysis technique that give description and full attention on accurately information media, which is data or the fact that is axist on the information media. The sample taken from warta kota newspaper from April until June. The study shows that patology in words taken from the topic of news reach $23 \%$. From the result/ we may draw a conclusion that the word that can cause patology is still low and still considered as tolerant.
\end{abstract}

Key words: Patology, language, news, newspaper

\section{PENDAHULUAN}

\section{LATAR BELAKANG}

Manusia harus berkomunikasi dengan manusia lainnya agar tetap dapat mempertahankan hidupnya. Pemertahanan hidup dengan memperoleh informasi dari orang lain dan memberikan informasi kepada orang lain, keinginan untuk mengetahui yang terjadi di sekitarnya, bahkan keingintahuan dengan yang terjadi di dunia (Kusumaningrat, 2005: 27). Tugas dan fungsi pers adalah mewujudkan semua keinginan tersebut melalui medianya, baik cetak, seperti koran, majalah, dan tabloit maupun elektronik, seperti radio, televisi, dan internet.
Salah satu media cetak adalah koran. Media koran itu sebagai salah satu media komunikasi cetak tidak dapat melepaskan diri dari aplikasi bahasa. Bahsa koran (jurnalistik) harus ringkas, mudah dipahami, dan langsung menerangkan apa yang dimaksudkan. Artinya, bahasa yang digunakan harus bersifat umum, yaitu mengikuti aturanaturan bahasa yang baku, mengikuti tata bahasa yang berlaku dan mempergunakan kosakata yang sama (Kusumaningrat, 2005: 164). Sebagai sebuah bahan bacaan, koran dapat mengunjungi pembaca setiap hari. Dengan beragam informasi, koran memenuhi ruang baca pembaca. Melalui informasi tersebut, hubungan akan tetap terjalin bagi yang berkepentingan. Media 
massa (koran) telah beredar hampir di seluruh pelosok nusantara. Dalam seluruh kalangan masyarakat dan dalam beragam kepentingan, manusia berhadapan dengan sumber informasi koran ini. Oleh sebab itu, media massa bukan hal yang baru, bahkan hampir seluruh penduduk Indonesia sudah mengenalnya, baik untuk dibaca maupun untuk mencari informasi. Media massa memiliki manfaat, terutama untuk menambah wawasan dan ilmu pengetahuan. Apabila kita dapat membacanya dengan rutin dan seksama, baik dalam perkembangan dunia, maupun untuk kepentingan yang lainnya, maka manfaatnya banyak bagi kehidupan.

Setiap orang dapat memperoleh informasi dan perkembangan setiap peristiwa dari seluruh dunia yang terjadi secara langsung serta dalam waktu yang cepat. Media massa memiliki kontribusi yang luar biasa bagi kemajuan bangsa dari berbagai segi kehidupan, terutama dari segi pengembangan dan pembinaan bahasa Indonesia. Salah satu kontribusi yang dimainkan media massa surat kabar harian pada hakikatnya adalah menanamkan kebiasaan membaca kepada masyarakat. Apabila semakin banyak masyarakat terbiasa membaca, lama kelamaan akan menjadi tradisi dan membudaya, sehingga terjadilah budaya membaca di kalangan masyarakat.

Pengaruh surat kabar dalam membentuk kebiasaan berbahasa di masyarakat pun sangat besar. Hal ini disebabkan oleh surat kabar terbukti dan mampu menjadi media yang efektif untuk dibaca. Kebiasaan surat kabar, dengan sendirinya dapat membiasakan orang atau pembaca menjadi semakin akrab dengan bahasa surat kabar. Namun pada kenyataanya, dari segi pemakai bahasa dalam surat kabar tergolong belum memadai. Masyarakat seakan tidak pernah berhenti untuk menuntut surat kabar supaya menggunakan bahasa yang standar dalam penyajian berita. Hal ini, seiring dengan peran pembinaan bahasa yang harus diusung oleh media surat kabar, sehingga media surat kabar benar-benar menjalankan fungsinya sebagai pencerdas kehidupan bangsa.

Hingga saat ini, tuntutan terhadap surat kabar sering terjadi karena surat kabar dianggap masih sering mengabaikan kaidah pemakaian bahasa Indonesia yang baik dan benar. Bahkan, dalam surat kabar, pembaca masih sering menemukan kesalahan pemakaian kata atau kesalahan dalam penulisan kata.

Contoh penggunaan kata dalam judul berita, di antaranya :

1. Polisi Bekuk Komplotan Bandit Spesialis Mobil.

2. Warga Kenari Menggunakan Jembatan Reyot.

3. Pengguna KRL Commuter line Numpuk.

4. Penusuk Bocah Cemburui Suami.

Sederet contoh judul berita di atas menunjukkan pemakaian kata yang sebenarnya tidak mendidik secara bahasa, akan tetapi kondisi kebahasaan seperti itu cenderung muncul dan digunakan oleh insan pers. Padahal, bahasa secara konvensional adalah sistem lambang bunyi yang selain bersifat arbitrer juga harus menghindari ambiguitas, hal ini berarti pemanfaatan bahasa harus sesuai dengan fungsi yang diusung oleh bahasa tersebut, yaitu yang dipergunakan oleh para anggota masyarakat untuk bekerja sama, berinteraksi, dan mengidentifikasikan diri.

Bahasa Indonesia adalah bahasa resmi negara Republik Indonesia dan hal itu disahkan pada 18 Agustus 1945 dan sebagai bahasa persatuan bangsa Indonesia yang secara politik termaktub dalam ikrar Sumpah Pemuda 28 Oktober 1928. Semakin majunya zaman dan semakin berkembangnya suatu negara maka semakin banyak pembiasaan 
bahasa dari bahasa baku berubah menjadi bahasa tidak baku, sebagai contoh dalam surat kabar. Surat kabar merupakan ragam tulis yang banyak diminati oleh para pembaca. Selain rubiknya variatif, berita juga dapat memberikan pengetahuan dan menambah wawasan pembaca. Tampilan judul berita juga sangat menentukan respon pembaca dalam pemilihan surat kabar.

Bentuk bahasa tulis dalam surat kabar Warta Kota, khususnya yang berkaitan dengan penulisan kata pada dasarnya masih terdapat kesalahan atau patologi yang dapat menimbulkan kekhawatiran. Ketepatan pemakaian dan penulisan kata dalam surat kabar tersebut memang masih terdapat fakta di luar asas yang berlaku. Padahal surat kabar sebagai media komunikasi yang menggunakan bahasa tulis tentunya harus tepat sesuai dengan kaidah penggunaan bahasa Indonesia yang baik dan benar.

Selain itu, pengetahuan para pembaca atas kemampuan pemakaian dan penulisan kata dalam sebuah surat kabar sangatlah penting. Dengan mengetahui kesesuainnya dengan kaidah ejaan, pembaca lebih tertarik dan setia terhadap surat kabar tersebut karena bukan hanya mampu mengajukan berita dan informasi yang aktual, tetapi surat kabar juga dapat menjadi teladan dalam hal kemampuan penerapan kaidah-kaidah yang berlaku.

Sebagai contoh, dalam pergaulan sehari-hari, peneliti dapat dengan mudah menemukan bentuk-bentuk tersebut muncul dengan maksud untuk mengakrabkan pergaulan atau membuat hubungan pertemanan menjadi akrab. Hal ini dapat dilihat dari penggunaan kata di lingkungan remaja yang cenderung menggunakan bahasa tidak baku dengan asumsi bahwa mereka terkontaminasi oleh adanya berita-berita di media cetak. Hal ini memotivasi peneliti melaksanakan penelitian dengan

\section{judul "Patologi Bahasa pada Judul Berita Surat Kabar Warta Kota".}

\section{TINJAUAN PUSTAKA \\ Hakikat Patologi}

Istilah 'patologi' muncul pada bidang kedokteran dan kimia namun dalam perkembangannya istilah ini masuk dalam berbagai disiplin ilmu termasuk bidang bahasa. Kenyataan ini dilihat dari aplikasi bahasa yang cenderung salah atau menyalahi kaidah dan proses pemaknaan yang keliru bagi setiap orang yang berhadapan dengan istilah tersebut. Untuk menyikapi masalah itu, peneliti mencoba mengangkat topik ini sebagai bahan kajian mengingat banyak beredar kosakatakosakata di tengah masyarakat sebagai konsumen berita yang disinyalir sebagai akibat membaca berita dengan suguhan bahasa yang salah.

Istilah 'patologi' mengacu kepada berbagai hal yang berhubungan degan penyakit trmasuk penyebab timbulnya. Demikian pula ketika patologi dikaitkan dengan bahasa, yang muncul adalah kesalahan bahasa dengan merujuk pada penyebab timbulnya kesalahan. Hal ini disebabkan oleh kurangnya pemahaman pemakai bahasa terkait masalah kesalahan atau hal-hal yang berhubungan dengan minimnya pengetahuan tentang kaidah bahasa atau tingginya pengaruh informasi yang dikemas dalam bahasa berita media. Oleh karena itu, berita dalam media harus memenuhi persyaratan tertentu atau terpenuhi unsur layak berita, misalnya, akurat, complete, fair, balanced, concise, clear, dan current (Kusumaningrat, 2005: 47).

Sifat-sifat istimewa berita ini sudah terbentuk sedemikian kuatnya sehingga sifat-sifat ini bukan saja menentukan bentuk-bentuk khas praktik pemberitaan, tetapi juga berlaku sebagai pedoman dalam penyajian dan penilaian 
layak tidaknya suatu berita untuk dimuat.

\section{Hakikat Judul Berita}

Frase judul berita adalah gabungan dua kata, yaitu kata judul dan kata berita. Kata judul dan berita mempunyai pengertian sendiri-sendiri. Judul adalah bagian dari karangan yang berfungsi untuk mengenal karangan yang bersangkutan. Judul berita memusatkan perhatian pada masalah yang dibahas atau dibicarakan, sedangkan berita mengandung pengertian sesuai dengan penyampaian dan jenis isinya. Judul berita merupakan bagian dari aktivitas jurnalistik. Judul berita menjadi hal yang penting dalam menarik perhatian pembaca.

Tidak ada berita yang menarik tanpa judul berita. Berita wajib diberi judul, Yunus (2010:76) menyatakan bahwa judul berita adalah untuk memicu keingintahuan pembaca, bukan sebaliknya malah membunuh minat pembaca. Begitu pentingnya kedudukan judul dalam suatu berita, menandakan perlunya keterampilan khusus dalam membuat judul berita yang baik.

Judul berita memang terkesan hal yang sepele. Namun, judul berita akan menjadi bagian yang sangat penting dalam suatu berita. Tidak sedikit surat kabar yang dibeli dan dibaca banyak orang karena penampilan judul berita yang menarik. Tidak sedikit pula berita yang sebenarnya bagus dan menarik, tetapi karena ketidaktepatan dalam membuat judul berita, menyebabkan berita tersebut tidak dibaca orang dan akan menjadi sia-sia.

Seorang penulis dalam membuat judul harus teliti untuk mendapatkan hasil judul berita yang menarik, Putra (2006:72) menyatakan bahwa judul berita itu sangat penting karena merupakan etalase atau pintu masuk, yang penting. Seorang redaktur perlu menimbang-nimbang dan akhirnya menetapkan sebuah judul yang baik.

Dilihat dari sisi kepentingan berita, Menurut Sumadiria (2006:121) judul berita adalah identitas berita. Tanpa judul, berita sehebat apapun tidak ada artinya. Judul berita sangat mendasar dilihat dari dua sisi kepentingan. Pertama, tanpa judul ia tidak dikenal, ia tidak mampu memberikan pesan. Kedua, judul adalah pemicu daya tarik pertama bagi pembaca untuk membaca berita.

Wahyudi (Harahap, 2006: 4) menyatakan bahwa berita adalah laporan tentang peristiwa atau pendapat yang memiliki nilai penting, menarik bagi sebagian khalayak, masih baru dan dipublikasikan secara luas melalui media massa. Berita merupakan suatu kejadian yang mempunyai nilai penting dan menarik bagi masyarakat, tentang suatu peristiwa yang baru untuk diinformasikan secara luas kepada pembaca melalui media massa.

Arifin, dkk. (2012:120) "Judul adalah kepala karangan, kata yang dipakai dalam bab dan buku. Judul menjadi sangat penting karena dianggap sebagai pintu informasi paling awal, ringkas, dan mewakili isi tulisan (karangan) yang disajikan."

Suhandang (2010:115) menyatakan bahwa :

"Pada hakikatnya judul berita merupakan intisari dari berita. Dibuat dalam satu kalimat atau dua kalimat pendek, tetapi cukup memberitahukan persoalan pokok peristiwa yang diberitakannya. Karena berita yang harus disajikan itu banyak dan masingmasing berita harus diminati dan dinikmati pembaca, pendengar atau penonton.maka judul berita pun tidak dibuat seragam diusahakan agar masing-masing berita dapat ditonjolkan lain dari yang lainnya." 
Berdasarkan definisi para ahli di atas dapat disimpulkan bahwa judul berita adalah kepala karangan yang menarik, singkat, padat, dan lugas. Judul berita dapat membangkitkan minat dan perhatian para pembaca. Jadi, berita tanpa judul akan sia-sia karena tidak ada pesan yang disampaikan.

Syarat-syarat judul berita

Menurut Yunus (2010:76-78) untuk dapat membuat judul berita yang baik diperlukan syarat-syarat judul berita. Syarat-syarat judul berita adalah sebagai berikut:

1. Provokatif

Judul berita yang profokatif lebih cenderung psikologis. Judul berita ini lebih menekankan untuk membangkitkan minat dan perhatian para pembaca. Judul berita yang provokatif mampu menggugah sikap, intuisi, dan emosi pembaca. Contoh, Akbar Tantang Mega, Mahasiswa Demo Rektor.

2. Singkat dan Padat

Judul berita harus singkat, padat, lugas, dan tegas. Judul berita tidak perlu bertele-tele. Isi berita yang singkat dan padat pada judul berita berkisar 3-7 kata. Judul berita yang singkat dan padat juga menjadi tuntutan karena terbatasnya spasi dan mampu menjadi bacaan sepintas pembaca. Contoh: Harga BBM Naik, Pesawat Presiden Jatuh.

3. Relevan

Judul berita harus berkaitan dengan teras berita atau berita terpenting yang ingin disampaikan. Judul berita mewakili berita yang disajikan. Judul berita tidak boleh keluar dari pesan ter-penting yang ingin disampaikan. Contoh: Akbar Tantang Mega (sebagai gambaran dari Akbar Tanjung untuk berkompetisi dengan Megawati dalam pencalonan Presiden).

\section{Fungsional}

Judul berita seharusnya menggunakan kata-kata yang tegas, lugas sesuai dengan fungsi informasinya. Kata-kata yang digunakan dalam judul harus berdiri sendiri, tidak ambigu, dan tidak tergantung pada kata yang lain. Kata-kata yang dipakai dalam judul berfungsi sebagai makna inti dari berita yang dibahasnya. Contoh: Acara Presiden Hari Ini Padat (fungsional), Acara Presiden Hari Ini Menerima Banyak Materi (tidak fungsional).

5. Bahasa Baku

Judul berita hendaknya menggunakan gaya bahasa yang baku. Baku di sini, tidak menyimpang dari kaidah makna dan bahasa yang lazim. Judul berita tidak sepatutnya menjadi contoh buruk perilaku berbahasa masyarakat. Etika berbahasa juga perlu diperhatikan dalam membuat judul berita. Jurnalistik juga mengemban misi edukasi kepada masyarakat dalam penyajian judul berita yang harus singkat, padat, lugas, dan tegas. Kreativitas berbahasa dalam membuat judul berita perlu dikembangkan. Contoh: Majikan dan Pembantu Berhubungan Intim (bahasa baku), Majikan dan Pembantu Ngesek Bareng (bahasa tidak baku).

6. Spesifik

Judul berita harus spesifik, bermakna jelas, tidak menimbulkan interpretasi yang berbeda. Artinya, judul berita perlu meng-gunakan kata-kata khusus yang makna dan ruang lingkupnya terentu, bukan memakai kata-kata umum yang makna dan ruang lingkupnya luas. Contoh: Harga Sembako Melonjak Bulan Ini (kata umum), Harga Beras dan Minyak Goreng Melonjak (kata khusus). 
Jadi, untuk mendapatkan judul yang baik harus memenuhi syarat-syarat seperti yang diutarakan di atas.

\section{Hakikat Media Massa}

1. Pengertian media massa kan bahwa:

Yunus (2010:26-27) menyata-

"Media massa dapat dikatakan sebagai sarana yang menjadi tempat penyajian hasil kerja aktivitas jurnalistik. Media massa merupakan istilah yang digunakan oleh publik dalam mereferansi tempat dipublikasikannya suatu berita. media massa dapat diartikan sebagai segala bentuk media atau sarana komunikasi yang menyalurkan dan mempublikasikan berita kepada publik atau masyarakat."

Jika dilihat dari jenisnya, Ardianto (2012:103) menyatakan bahwa Media massa pada dasarnya dapat dibagi menjadi dua kategori, yakni media massa cetak dan media massa elektronik. Media cetak yang dapat memenuhi kriteria sebagai media massa adalah siaran radio, televisi, film, media online (internet). Setiap media cetak mempunyai kriteria yang khas.

Tambrini (2012:98) menyatakan bahwa:

"Media massa bukanlah benda mati yang hanya dapat dimanfaatkan oleh mereka yang memiliki kepentingan politik. Lebih dari itu, media massa juga dapat membentuk opini publik yang memberikan sajian-sajian tertentu yang terkadang subjektif. Lewat sajian-sajian pemberitahuan sesungguhnya media massa dapat mewarnai khasanah perpolitikan nasional yang dilaporkan oleh seorang reporter atau wartawan."

Pers mengandung dua arti, yaitu arti sempit dan arti luas. Dalam arti sempit, pers hanya menunjuk kepada media cetak, seperti surat kabar, tabloid, dan majalah, sedangkan dalam arti luas, pers bukan hanya menunjuk media cetak berkala melainkan juga mencangkup media elektronik, yakni radio, televise, film, dan media internet. Pers dalam arti luas disebut media massa (Sumadiria, 2006:31).

Dari pendapat di atas, dapat disimpulkan bahwa media massa adalah segala bentuk media atau sarana komunikasi yang menyalurkan dan mempublikasikan berita kepada masyarakat luas, sedangkan berita merupakan laporan tercepat mengenai fakta yang telah terjadi dan menarik perhatian publik yang memiliki sifat informatif, layak dipublikasikan, dan sebagai hasil karya jurnalistik.

2. Jenis Media

Menurut Yunus (2010:27) dalam dunia jurnalistik, media dikatagorikan ke dalam tiga jenis, yaitu:

a. Media cetak, seperti koran, tabloid, surat kabar

b. Media elektronik, seperti televisi, radio

c. Media online, seperti internet

Dari penjelasan di atas dapat penulis simpulkan bahwa media massa dikatagorikan ke dalam tiga jenis, yakni media cetak, media elektronik, dan media online

\section{Hakikat Kata Baku}

1. Pengertian Kata Baku

Arifin dan Tasai (2006:21) menyatakan bahwa "Ragam baku 
adalah ragam yang dilembagakan dan diakui oleh sebagian besar warga masyarakat pemakainya sebagai bahasa resmi dan sebagai kerangka rujukan norma bahasa dalam penggunaannya."

Menurut Chaer (2006:4) kata baku adalah satu ragam bahasa yang dijadikan pokok, yang dijadikan dasar ukuran atau yang dijadikan standar. Penggunaan bahasa oleh masyarakat dijadikan ukuran kebakuan bahasa, walaupun kesepakatan sosial itu dimulai dengan prakarsa seseorang atau prakarsa sekelompok orang, baik dalam bentuk formal maupun nonformal.

Dengan demikian, kenyataan penggunaan bahasa oleh pemimpin masyarakat yang bersangkutan tidak selamanya dijadikan ukuran kebakuan bahasa walaupun kesepakatan sosial itu dimulai dengan prakarsa seseorang atau prakarsa sekelompok orang, baik dalam bentuk yang formal maupun nonformal.

Dari teori di atas, dapat disimpulkan bahwa kata baku adalah kata yang mengikuti kaidah bahasa yang berlaku dengan berpedoman pada ejaan, tata bahasa baku, dan penggunaannya disesuaikan dengan situasi. Maksudnya adalah bahwa dalam proses komunikasi ada saatnya kita dituntut untuk menggunakan bahasa baku.

2. Ciri-ciri Bahasa Baku

\section{Dalam Pedoman umum}

Ejaan Bahasa Indonesia, bahasa baku mempunyai ciri-ciri sebagai berikut, Tidak dipengaruhi bahasa daerah, Tidak dipengaruhi bahasa asing, Bukan merupakan bahasa percakapan, Pemakaian imbuhan secara eksplisit, Pemakaian yang sesuai dengan konteks kalimat, Tidak memiliki makna ganda, tidak rancu, Tidak memilki arti pleonasme, dan Tidak terdapat makna hiperkorek.

Dari penjelasan di atas dapat penulis simpulkan bahwa bahasa baku itu memiliki delapan (8) ciri utama

3. Fungsi Bahasa Baku

Menurut Alwi, dkk. (2003:14) bahasa baku mempunyai empat fungsi, tiga di antaranya bersifat pelambang atau simbolik, sedangkan yang satu lagi bersifat objektif.

a. Fungsi pemersatu, bahasa baku menghubungkan semua penutur berbagai dialek bahasa. Dengan demikian, bahasa baku mempersatukan mereka menjadi satu masyarakat bahasa dan meningkatkan proses identifikasi penutur seseorang dengan seluruh masyarakat.

b. Fungsi pemberi kekhasan, yang diemban oleh bahasa baku membedakan bahasa itu dari bahasa yang lain.

c. Fungsi pembawa kewibawaan, bersangkutan dengan usaha orang mencapai kesederajatan dengan peradaban lain yang dikagumi lewat bahasa baku tersebut.

d. Fungsi sebagai kerangka acuan, bagi pemakaian bahasa dengan adanya norma dan kaidah yang jelas.

Dari penjelasan di atas dapat penulis simpulkan bahwa bahasa baku mempunyai empat fungsi, yaitu sebagai pemersatu, pemberi kekhasan, pembawa kewibawaan, dan sebagai kerangka acuan. 


\section{METODE PENELITIAN}

Penelitian ini merupakan penelitian kualitatif dengan pendekatan atau metode deskriptif. Margono (2003:36) menyatakan bahwa penelitian kualitatif adalah prosedur penelitian yang menghasilkan data deskriptif berupa kata-kata tertulis atau lisan dari orang-orang dan perilaku yang dapat diamati.

Metode deskriptif bertujuan untuk menggambarkan sifat sesuatu yang telah berlangsung pada saat riset dilakukan dan memeriksa sebab-sebab dari suatu gejala tertentu.

\section{HASIL DAN PEMBAHASAN}

Dari data yang terkumpul, peneliti mencoba menganalisis sesuai dengan kaidah kebakuan bahasa agar terhindar dari patologi bahasa. Berdasarkan ada dan tidaknya penggunaan kata baku tersebut, maka proses analisis data dilakukan dengan cara menganalisis penggunaan kata tidak baku yang terdapat pada judul berita surat kabar warta kota.

Contoh kasus dan Analisis:

1. Penusuk Bocah Cemburui Suami

Kata Bocah setelah diubah menjadi kata baku maka judul tersebut menjadi seperti berikut:

Penusuk anak cemburui suami.

2. Pengguna KRL commuter line nyaris sama dengan KRL Ekonomi Numpuk Kata Numpuk setelah diubah menjadi kata baku maka judul tersebut menjadi seperti berikut:

Pengguna KRL commuter line nyaris sama dengan KRL ekonomi menumpuk.

3. Polisi Bekuk Komplotan Bandit Spesialis Mobil
Kata Bekuk, Komplotan, dan Bandit setelah diubah menjadi kata baku maka judul tersebut menjadi seperti berikut:

Polisi menangkap kelompok pencuri spesialis mobil.

4. Warga DKI Sulit Bayar PBB

Kata Bayar setelah diubah menjadi kata baku maka judul tersebut menjadi seperti berikut:

Warga DKI sulit membayar PBB.

5. Selama 20 Menit Rampok Gasak Rp 6,3 Miliar

Kata Rampok dan Gasak setelah diubah menjadi kata baku maka judul tersebut menjadi seperti berikut:

Selama 20 Menit perampok mengambil $\mathrm{Rp}$ 6,3 miliar.

6. Pembunuh Putra Konglomerat Bandung Dibekuk di Bangkok

Kata Dibekuk setelah diubah menjadi kata baku maka judul tersebut menjadi seperti berikut:

Pembunuh putra konglomerat Bandung ditangkap di Bangkok.

7. Siswa Miskin Tak Kuat Bayar Bimbel

Kata Tak dan Bayar setelah diubah menjadi kata baku maka judul tersebut menjadi seperti berikut:

Siswa miskin tidak kuat membayar bimbel.

8. Warga Kenari Menggunakan Jembatan Reyot

Kata Reyot setelah diubah menjadi kata baku maka judul tersebut menjadi seperti berikut:

Warga Kenari menggunakan jembatan rusak.

9. Pengelola Investasi Bodong Diciduk 
Kata Bodong dan Diciduk setelah diubah menjadi kata baku maka judul tersebut menjadi seperti berikut:

Pengelola Investasi palsu ditangkap.

10. Perampok Pengadilan Nyamar Petani

Kata Nyamar setelah diubah menjadi kata baku maka judul tersebut menjadi seperti berikut:

Perampok Pengadilan Menyamar petani.

11. Polisi Tembak Bandit Pecah Kaca Kata Tembak, Bandit, dan Pecah setelah diubah menjadi kata baku maka judul tersebut menjadi seperti berikut:

Polisi Menembak Pencuri Pecahkan Kaca.

12. Kepala SMA Galau Hasil TO Jeblog Kata Galau dan Jeblog setelah diubah menjadi kata baku maka judul tersebut menjadi seperti berikut:

Kepala Sekolah SMA Resah Hasil TO Menurun.

13. Tiara Cium Tangan Bunda Mohon Doa

Kata Cium setelah diubah menjadi kata baku maka judul tersebut menjadi seperti berikut:

Tiara Mencium Tangan Bunda Mohon Doa

14. KPK Tangkap Pegawai Pajak Dan Pembalap

Kata Tangkap setelah diubah menjadi kata baku maka judul tersebut menjadi seperti berikut:

KPK Menangkap Pegawai Pajak dan Pembalap

15. Pistol Renggut Nyawa Bos Keramik Kata Pistol dan Renggut setelah diubah menjadi kata baku maka judul tersebut menjadi seperti berikut:
Senapan Merenggut Nyawa Bos Keramik.

16. 3 Pria Kurir Diciduk Bawa Ratusan Ribu Ekstasi

Kata Diciduk dan Bawa setelah diubah menjadi kata baku maka judul tersebut menjadi seperti berikut:

3 Pria Kurir Ditangkap Membawa Ratusan Ribu Ekstasi.

17. Siswa SMK Penerima KTP Pakai HP Galaxy

Kata Pakai dan HPsetelah diubah menjadi kata baku maka judul tersebut menjadi seperti berikut:

Siswa SMK Penerima KTP Memakai Telepon Genggam Galaxy.

18. Mega Merasa Dikuntit Intel

Kata Dikuntit setelah diubah menjadi kata baku maka judul tersebut menjadi seperti berikut:

Mega Merasa Diikuti Intel.

19. Tangan Rusmaya Gemetar Saat Ambil Pelampung

Kata Ambilsetelah diubah menjadi kata baku maka judul tersebut menjadi seperti berikut:

Tangan Rusmaya Gemetar Saat Mengambil Pelampung.

20. Negara Masih Bisa Sita Harta Gayus Kata Sita setelah diubah menjadi kata baku maka judul tersebut menjadi seperti berikut:

Negara Masih Bisa Menyita Harta Gayus.

Dari data di atas dan hasil analisis dapat ditemukan adalah bahwa judul berita Warta Kota terbukti memiliki tingkat kata tidak baku mencapai 115 kata atau 23\%. Hal ini menunjukan bahwa surat kabar Warta Kota dalam penulisan judul berita mengunakan kata tidak baku cenderung konsisten. Dalam konteks inilah, ternyata masih terdapat 
judul berita dalam surat kabar Warta Kota yang masih menggunakan kata tidak baku, sehingga kurang memperhatikan aspek kaidah penulisan dan pemakaian kata secara baik dan benar. Dengan demikian, kondisi ini akan memberikan dampak yang tidak baik terhadap pemakaian bahasa pembaca.

\section{SIMPULAN}

Berdasarkan hasil penelitian di atas, dapat disimpulkan bahwa penggunaan kata tidak baku lebih sedikit dibandingkan dengan penggunaan kata baku, kata baku lebih mendominasi judul berita. Kata baku jumlah nya lebih banyak. Jumlah kata tidak baku yang terdapat pada judul berita halaman pertama surat kabar Warta Kota sebanyak 115 kata, sedangkan kata baku yang digunakan sebanyak 385 kata. Penggunaan kata tidak baku yang terdapat pada judul berita halaman pertama surat kabar Warta Kota disebabkan karena penggunaan bahasa seharihariyang sudah menjadi kebiasaan. Dengan demikian, judul berita surat kabar Warta Kota dapat dikatakan cukup baik, karena kata-katanya mudah untuk dipahami.

Penggunaan kata tidak baku atau yang dianggap patologi terdapat $115 \mathrm{kata}$ atau mecapai $23 \%$. judul berita halaman pertama surat kabar Warta Kota tergolong rendah atau dapat ditoleransi. Warta Kota memiliki banyak rubik yang ditampilkan, tetapi masih ada judul berita yang dianggap menyalahi tatanan kaidah berbahasa yang baik dan benar. Setiap judul berita penulis tidak selalu menggunakan pilihan kata baku, sehingga menimbulkan kesalahan atau patologi dalam berbahasa.

\section{DAFTAR PUSTAKA}

Alwi, H, dkk. (2003). Tata Bahasa Baku Bahasa Indonesia. Jakarta: Balai Pustaka.

Arifin, Z. dan Amran, T. (2006). Cermat Berbahasa Indonesia. Jakarta: Akapres.

Kajian Wacana Bahasa
Indonesi. Tagerang: PT Pustaka
Mandiri.

Ardianto, E. dkk. (2012). Komunikasi Massa. Bandung : Simbiosa Rekatama Media.

Chaer.,A. (2006). Tata Bahasa Praktis Bahasa Indonesia. Jakarta: Rineka Cipta.

Harahap, A.S. (2006). Jurnalistik Televisi. Bogor: Indeks.

Haris, S. (2006). Bahasa Jurnalistik Panduan Praktis Penulis dan Jurnalistik. Bandung: Simbiosa Rekatama Media.

Kusumaningrat, H. dan Kusumaningrat, P. (2005). Jurnalistik: Teori dan Praktik. Bandung: PT Remaja Rosdakarya.

Margono. (2003). Metodologi Penelitian Penelitian. Jakarta: PT Rineka Cipta.

Putra, R.M.S. (2006). Teknik Penulisan Berita dan Feature. Jakarta: Indeks.

Rohman, S. (2012). Pengantar Pengajaran Sastra. Jogjakarta: Ar- Ruzz Media.

Sumadiria, H. (2006). Jurnalistik Indonesia. Bandung: Simbiosa Rekatama Media.

Subana dan Sunarti. (2011). Strategi Belajar Pembelajaran Bahasa 
Indonesia. Badung: Pustaka Setia.

Suhandang, K. (2010). Pengantur Jurnalistik Seputar Organisasi, Produk, dan Kode Etik. Bandung : Nuansa.

Tim CSG. 2012. Aturan Terbaru EYD untuk Pelajar, Mahasiswa, dan Umum. Jogjakarta: Cakrawala.
Tambroni, R. (2012). Komunikasi Politik pada Era Multimedia. Bandung Simbiosa Rekatama Media.

Wassio, I. dan Sunendar, D. (2008). Strategi Pembelajaran Bahasa. Bandung: PT Remaja Rosdakarya.

Yunus, S.(2010). Jurnalistik Terapan. Jakarta: Ghalia Indonesia. 